\title{
Variabilitas Musiman Daerah Potensial Ikan di WPP-RI 711 Periode 2016-2018
}

\author{
Gusti Irsan Permana $^{1 *}$, Arie A. Kushadiwijayanto, Dwi Imam Prayitno1 \\ 1 Program studi Ilmu Kelautan, FMIPA, Universitas Tanjunpura, Pontianak- \\ Indonesia \\ *Correspondence email: Gusti Irsan Permana \\ $\bowtie$ gusti_irsan@hotmail.com
}

\section{Received:26 September 2019- Accepted: 2 October 2019 Published: 31 October 2019 (C) Author(s) 2019. This article is open access}

\begin{abstract}
Data Suhu Permukaan laut (SPL) dan Klorofil-a Satelit Aqua/Terra MODIS Level 2 tahun 2016 hingga 2018 telah digunakan untuk mengkaji variabilitas musiman Daerah Potensial Ikan (DPI) di WPP-RI 711. DPI ditentukan berdasarkan keberadaan thermal front dan konsentrasi klorofil-a pada daerah kajian. Thermal front ditentukan dengan menggunakan metode Single Image Edge Detection (SIED) dan klorofil-a ditentukan menggunakan konsentrasi sebesar $0,2-1 \mathrm{mg} / \mathrm{m} 3$. Luasan DPI yang digunakan adalah 10 x 10 mil laut. Hasil penelitian menunjukkan pola yang berbeda pada setiap musim. Pada musim barat, DPI yang ditemukan sebanyak 43 buah dengan sebaran terbanyak berada di sebelah barat Pulau Kalimantan dan di sekitar Kepulauan Natuna. Pada musim peralihan 1 (antara musim barat dan musim timur) terdapat 70 buah DPI dan tersebar merata di hampir seluruh wilayah kajian. Pada musim timur DPI hanya ditemukan sebanyak 14 buah dan terbanyak ditemukan di antara Pulau Bangka dan Pulau Belitung. Sedangkan pada musim peralihan 2 (antara musim timur dan musim barat) ditemukan DPI sebanyak 19 buah dengan keberadaan terbanyak berada di bagian utara Kepulauan Natuna. Keberadaan DPI terbanyak dijumpai pada musim peralihan 1 dan paling sedikit ketika musim timur. Peningkatan jumlah DPI terjadi dari musim barat hingga musim peralihan 1 . Penurunan jumlah DPI terjadi pada musim peralihan 1 menuju musim timur, namun mengalami kenaikan kembali pada musim peralihan 2 dan musim barat.
\end{abstract}

Keywords: Daerah Potensial Ikan (DPI), Wilayah Pengelolaan Perikanan Republik Indonesia 711 (WPP-RI 711)

\section{Pendahuluan}

Kalimantan Barat merupakan salah satu provinsi dengan garis pantai terpanjang di Indonesia. Garis pantai sepanjang $1.398 \mathrm{~km}$ bahkan melebihi keseluruhan panjang dari pantai utara pulau Jawa. Kondisi yang berbatasan langsung dengan Wilayah Pengelolaan Perikanan Republik Indonesia 711 (WPP-RI 711) menjadi sebuah potensi tersendiri bagi provinsi tersebut. Namun potensi tersebut belum dapat dijadikan sebagai tolok ukur kesejahteraan masyarakat yang hidup di pesisirnya. Sebagian besar masyarakat pesisir disana merupakan nelayan tradisional yang masih menerapkan pola pikir "mencari ikan". Penggunaan naluri dan kebiasaan menjadi faktor utama dalam penentuan lokasi penangkapan ikan oleh nelayan tradisional. Safitri dan Adelita (2018) menyatakan bahwa pada musim barat, nelayan Kalimantan Barat banyak melakukan 
kegiatan penangkapan ikan di perairan Tambelan, Pejantan, bahkan hingga di Kepulauan Natuna. Pada musim peralihan, kegiatan penangkapan juga dilakukan hampir di semua daerah penangkapan termasuk di perairan Laut Natuna dan Anambas. Sedangkan pada musim timur, nelayan melakukan kegaiatan penangkapan di perairan Kepulauan Natuna Besar hingga Kepulauan Riau (Safitri dan Adelita, 2018).

Pemanfaatan teknologi di bidang perikanan khususnya penginderaan jauh dapat diterapkan untuk membantu nelayan lokal dalam penentuan lokasi penangkapan ikan. Pendugaan daerah potensial ikan dapat dilakukan dengan menggunakan data satelit penginderaan jauh, seperti pencarian thermal front (Jatisworo dan Murdimanto, 2013) dan konsentrasi klorofil-a (Suniada et al., 2015) yang merupakan salah satu indikator kesuburan perairan dan tempat gerombolan ikan. Salah satu metode yang umumnya digunakan untuk penentuan daerah potensial penangkapan ikan dengan memanfaatkan teknologi penginderaan jauh adalah metode Single Image Edge Detection (SIED).

Dengan pemanfaatan teknologi penginderaan jauh yang efektif, maka kegiatan penangkapan ikan akan menjadi semakin optimal sehingga diharapkan kesejahteraan nelayan lokal akan meningkat. Jika keberadaan daerah potensial ikan telah diketahui, maka akan dapat memberikan informasi mengenai kesuburan suatu perairan yang hubungannya dengan daerah penangkapan ikan. Sehingga penelitian ini dapat menjadi referensi dan berguna untuk memaksimalkan potensi dari WPP-RI 711 yang meliputi Selat Karimata, Laut Natuna, dan Laut Natuna Utara. Serta diharapkan dapat membantu nelayan lokal dalam penentuan lokasi penangkapan ikan sehingga akan berdampak kepada kondisi perekonomian nelayan di kedepannya.

\section{Metode}

\subsection{Data}

Penelitian ini menggunakan data harian citra Satelit Aqua/Terra MODIS selama tahun 2016 hingga tahun 2018. Data citra yang digunakan adalah Suhu Permukaan Laut (SPL) dan konsentrasi klorofil-a Level 2 yang diunduh melalui laman resmi Ocean Color (http://oceancolor.gsfc.nasa.gov/). Sedangkan wilayah kajian dalam penelitian ini adalah Wilayah Pengelolaan Perikanan Republik Indonesia 711 (WPP-RI 711) yang terdiri atas Selat Karimata, Laut Natuna, dan Laut Natuna Utara.

\subsection{Pengolahan Data}

Pengolahan data dibagi menjadi beberapa tahapan. Yaitu koreksi radiometrik dan geometrik untuk menjaga quality control, pembuatan peta Daerah Potensial Ikan (DPI), serta pembuatan peta frekuensi daerah potensial ikan.

Adapun quality control untuk SPL adalah $24 \mathrm{oC}-31{ }^{\circ} \mathrm{C}$ (Kurniawan et al., 2015) dan klorofil-a adalah $0,2 \mathrm{mg} / \mathrm{m} 3$ - $1 \mathrm{mg} / \mathrm{m} 3$ dengan asumsi nilai klorofil-a dibawah 0,2 $\mathrm{mg} / \mathrm{m} 3$ merupakan daerah yang kurang subur sedangkan daerah dengan konsentrasi klorofil-a diatas $1 \mathrm{mg} / \mathrm{m} 3$ diasumsikan adanya bias akibat kondisi perairan yang kompleks (Suniada et al., 2016 ; Susanto et al., 2001 ; BROL, 2018).

Penentuan DPI didasarkan pada sebaran klorofil-a dan thermal fronts. Penentuan thermal fronts dilakukan dengan alat bantu Marine Geospatial Ecology Tools (Roberts et al., 2010) dan menggunakan metode SIED (Cayula \& Cornillon, 1992) dengan treshold atau perbedaan suhu $0,5{ }^{\circ} \mathrm{C}$ (Simbolon dan Tadjuddah, 2008 ; BROL, 2018).

Peta frekuensi daerah potensial ikan dibuat berdasarkan keberadaan DPI di sebuah transek dalam kurun waktu tertentu. Transek yang digunakan berukuran 10x10 mil laut dan berdasarkan kriteria kesesuaian lokasi DPI yang dikeluarkan LAPAN pada tahun 2014. Adapun kriteria kedekatan posisi DPI dengan lokasi penangkapan oleh nelayan terbagi menjadi 4 kriteria yaitu radius 10, 20, 30 dan 60 mil laut (LAPAN, 2014). Penentuan frekuensi didasarkan pada jadwal terbit Peta Prakiraan Daerah Potensial Ikan (PPDPI) yang dikeluar oleh Balai Riset dan Observasi Laut (BROL), yaitu pada hari Senin, Rabu, dan Jumat atau berjarak 2 hari. Sehingga dalam penelitian ini 1 frekuensi didasarkan pada DPI yang berada pada transek selama minimal 1 hari dan maksimal 2 hari.

\section{Hasil dan Pembahasan}

\subsection{Sebaran Daerah Potensial Ikan Selama Musim Barat}

Pada Musim Barat terdapat 43 buah DPI seperti dalam Gambar 1. Terdapat 29 DPI dengan frekuensi 1, 9 DPI dengan frekuensi 2, 2 DPI dengan frekuensi 3, dan 3 DPI dengan frekuensi 4. Semakin tinggi frekuensi 


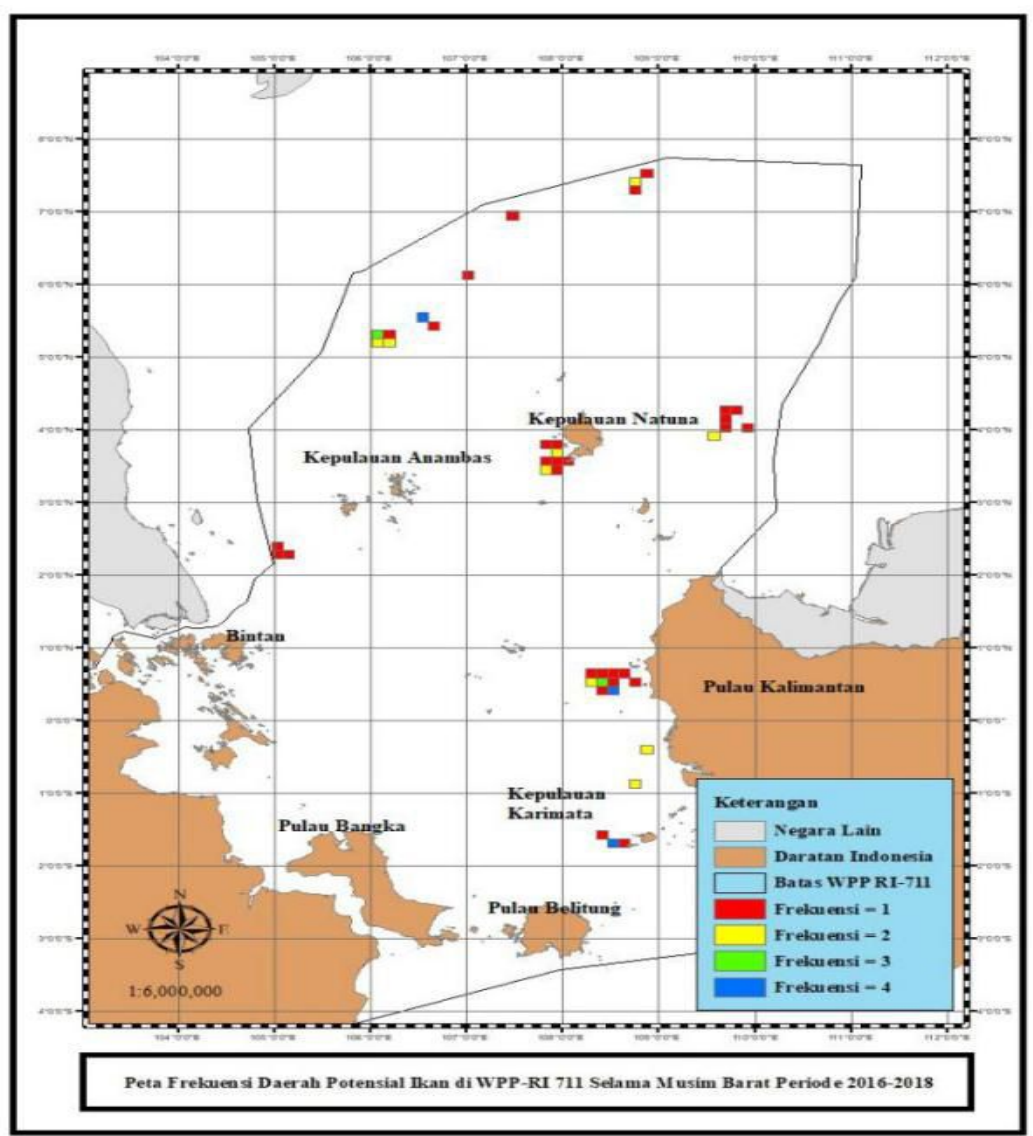

Gambar 1. Peta Frekuensi Daerah Potensial Ikan di WPP-RI 711 Selama Musim Barat (Desember, Januari, dan Februari)

DPI maka semakin sering terjadi kemunculan DPI pada wilayah tersebut selama periode 2016 hingga 2018.

Pada musim ini, DPI dengan frekuensi 1 memiliki jumlah paling banyak dan tersebar ke berbagai penjuru WPP-RI 711. Pada bagian barat Pulau Kalimantan terdapat 7 buah DPI dengan frekuensi 1 dan 2 buah di sekitar Kepulauan Karimata. Terdapat 3 buah DPI pada bagian barat daya Kepulauan Anambas atau timur laut Bintan. Di sekitar Kepulauan Natuna, DPI tersebar cukup merata. 6 buah DPI berada di bagian barat hingga barat daya Kepulauan Natuna. Lima buah DPI berada di bagian timur, serta 6 buah tersebar di bagian utara Kepulauan Natuna dan tidak jauh dari batas WPP-RI 711.

DPI dengan frekuensi 2 memiliki jumlah kedua terbanyak pada musim ini. Terdapat 9 buah DPI dalam kurun waktu 2016 hingga 2018. Terdapat 3 buah DPI dengan frekuensi ini pada bagian barat Pulau Kalimantan. Dua buah di bagian barat hingga barat daya Kepulauan Natuna, serta 1 buah di sebelah timur Kepulauan Natuna. Selain itu, terdapat juga 3 buah DPI dengan frekuensi 2 pada bagian utara dan barat laut Kepulauan Natuna serta berbatasan dengan batas WPP-RI 711.

Terdapat 2 buah DPI dengan frekuensi 3 dan 3 buah DPI dengan frekuensi 4 pada musim ini. Satu buah DPI dengan frekuensi 3 terdapat pada bagian barat Pulau Kalimantan dan 1 buah lagi terdapat pada bagian barat laut Kepulauan Natuna, tidak jauh dari batas WPP-RI 711. Terdapat 1 buah DPI dengan frekuensi 4 di bagian barat laut Kepulauan Natuna, 1 buah di Kepulauan Karimata, dan 1 buah lagi di bagian barat Pulau Kalimantan.

Ketika Musim Barat, Bumi bagian utara sedang mengalami musim dingin sehingga air laut yang berada pada bumi bagian utara dengan suhu yang rendah bergerak menuju Laut Natuna Utara dan bertemu dengan massa air yang lebih hangat yang berasal dari perairan Indonesia. Pertemuan dua jenis massa air yang berbeda suhu tersebut menyebabkan terbentuknya thermal fronts. Pergerakan angin yang condong cukup cepat juga turut berperan dalam membantu pergerakan air. Sehingga pada musim ini terdapat cukup banyak keberadaan DPI. Pada 


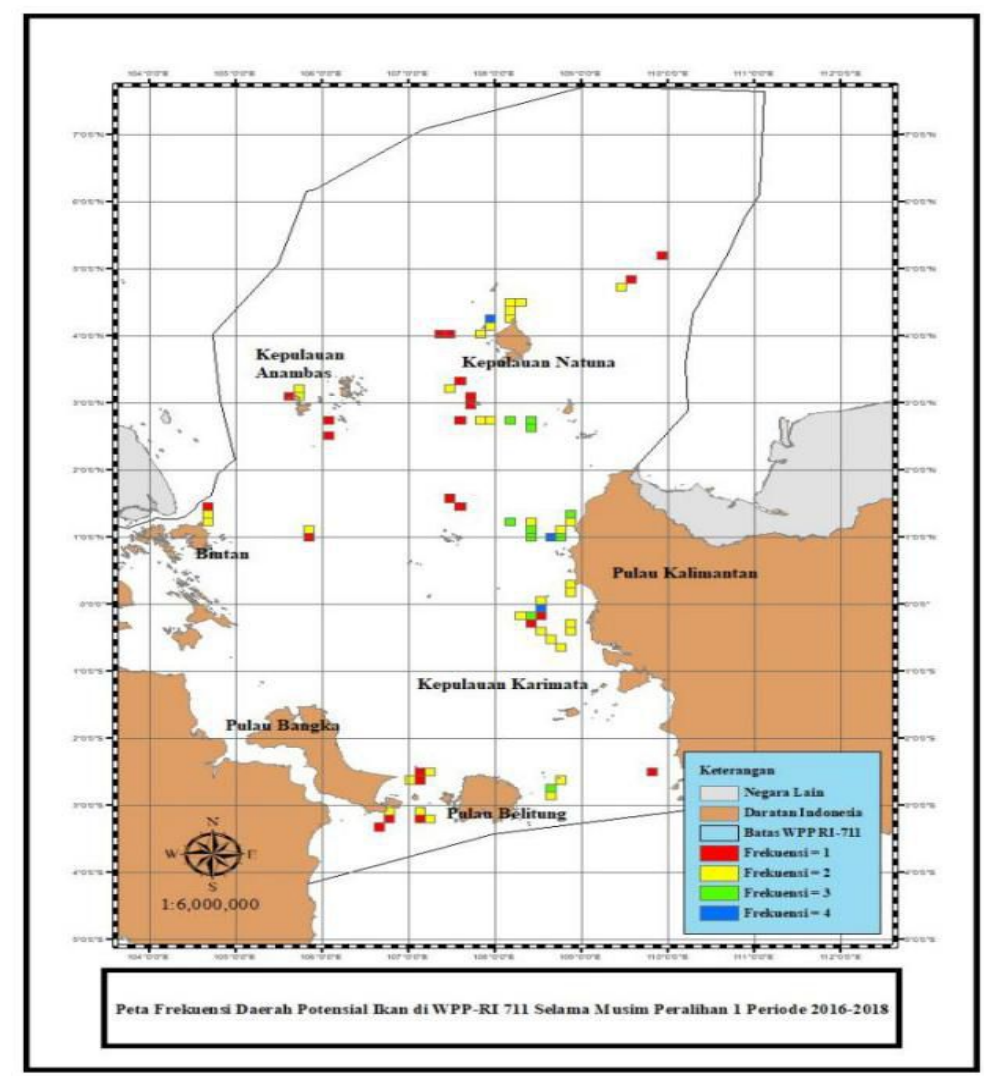

Gambar 2. Peta Frekuensi Daerah Potensial Ikan di WPP-RI 711 Selama Musim Peralihan 1 (Maret, April, dan Mei

musim ini DPI terbanyak ditemukan di sebelah Barat Pulau Kalimantan dan di sekitar Kepulauan Natuna.

\subsection{Sebaran Daerah Potensial Ikan Selama Musim Peralihan 1}

Pada Musim Peralihan 1 terdapat Daerah Potensial Ikan (DPI) dengan jumlah terbanyak yaitu 70 buah seperti pada Gambar 2. Terdapat 23 buah DPI dengan frekuensi 1 dan 34 buah DPI dengan frekuensi 2. Selain itu juga terdapat 10 buah DPI dengan frekuensi 3 dan 3 buah DPI dengan frekuensi 4.

Pada musim ini, DPI dengan frekuensi 1 tersebar cukup merata di WPP-RI 711. Terdapat 5 buah diantara Pulau Bangka dan Pulau Belitung. Terdapat 5 buah pada bagian barat Pulau Kalimantan dan tersebar cukup merata mulai dari barat laut hingga barat daya pulau tersebut. Terdapat 1 buah pada bagian timur laut Bintan dan 1 buah lagi pada bagian timurnya. Terdapat 3 buah di sekitar Kepulauan Anambas serta 8 buah di sekitar Kepualauan Natuna.

DPI dengan frekuensi 2 ditemui paling banyak pada musim ini. Terdapat 34 buah dan tersebar cukup merata di bagian-bagian WPP-RI 711. Terdapat 5 buah diantara Pulau
Bangka dan Pulau Belitung, serta 2 buah pada bagian timur Pulau Belitung.

Terdapat 12 buah pada bagian barat Pulau Kalimantan, 2 buah pada bagian timur laut Bintan dan 1 buah lagi pada bagian timur Bintan. Selain itu juga terdapat 2 buah DPI dengan frekuensi 2 di sekitar Kepulauan Anambas. DPI dengan frekuensi ini tersebar cukup merata di sekitar Kepulauan Natuna, 1 buah pada bagian barat daya, 2 buah pada bagian selatan, 1 buah pada bagian timur laut, serta 6 buah pada bagian utara.

Pada musim ini, terdapat 10 buah DPI dengan frekuensi 3 dan 3 buah DPI dengan frekuensi 4. Satu buah DPI dengan frekuensi 3 berada di sebelah timur Pulau Belitung dan 6 buah pada bagian barat Pulau Kalimantan. Selain itu terdapat juga 3 buah DPI dengan frekuensi 3 di sebelah utara Kepulauan Natuna. Terdapat 1 buah DPI dengan frekuensi 4 di sebelah barat laut Kepulauan Natuna dan 2 buah lagi di sebelah barat pulau Kalimantan.

Pada Musim Peralihan 1 kondisi angin relatif lebih tenang sehingga pengadukan oleh angin condong rendah. Selain itu, masukan air tawar yang berasal dari sungai-sungai di Kalimantan dan Sumatera mengandung banyak nutrisi. Air yang berasal 


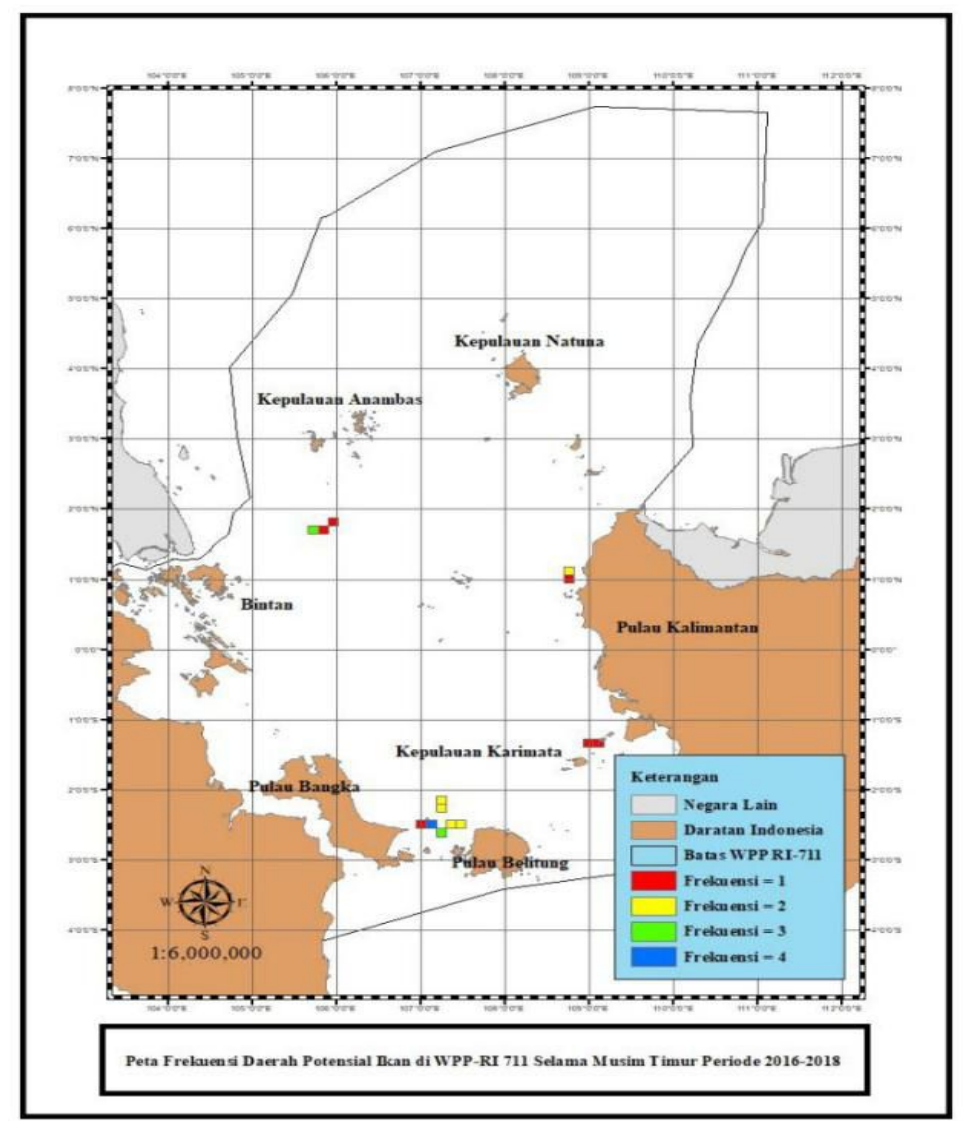

Gambar 3. Peta Frekuensi Daerah Potensial Ikan di WPP-RI 711 Selama Musim Peralihan Timur (Juni, Juli, dan Agustus)

dari sungai memiliki suhu yang lebih rendah daripada air laut, sehingga ketika massa air sungai yang memiliki suhu lebih dingin bertemu dengan massa air laut yang memiliki suhu lebih hangat akan menyebabkan terbentuknya thermal fronts. Kondisi angin yang relatif lebih tenang tersebut menyebabkan massa air sungai tidak menyebar terlalu jauh. Sehingga keberadaan daerah potensial ikan condong tersebar di dekat wilayah daratan dan kepulauan. Pada musim ini DPI tersebar cukup merata di hampir seluruh bagian WPP-RI 711.

\subsection{Sebaran Daerah Potensial Ikan Selama Musim Timur}

Pada Musim Timur jumlah DPI yang ditemukan paling sedikit diantara musim lainnya. Terdapat 14 buah DPI seperti pada Gambar 3. Enam buah DPI dengan frekuensi 1, 5 buah dengan frekuensi 2, 2 buah dengan frekuensi 3, dan 1 buah dengan frekuensi 4 .

Pada musim ini terdapat 3 buah DPI dengan frekuensi 1 di bagian barat Pulau Kalimantan, 1 buah di antara Pulau Bangka dan Pulau Belitung, serta 2 buah di selatan Kepulauan Anambas atau timur laut Bintan.
Terdapat 1 buah DPI dengan frekuensi 2 di sebelah barat Pulau Kalimantan dan 4 buah lagi diantara Pulau Bangka dan Pulau Belitung. Selain itu juga terdapat 1 buah DPI dengan frekuensi 3 di bagian selatan Kepulauan Anambas serta 1 buah lagi diantara Pulau Bangka dan Pulau Belitung. Selain itu, juga terdapat 1 buah DPI dengan frekuensi 4 di antara Pulau Bangka dan Pulau Belitung.

Pada Musim Timur, kondisi suhu permukaan laut lebih hangat dan kondisi angin cukup tenang. Sehingga masukan air tawar yang berasal dari daratan tidak tersebar cukup jauh dan cenderung di tepian pantai. Namun dari hasil koreksi citra, bagian tepian daratan lebih banyak terkoreksi sehingga sulit ditemukan keberadaan DPI yang berada di tepian pantai. Hal tersebutlah yang diduga menjadi penyebab utama sedikitnya jumlah DPI pada Musim Timur.

Berdasarkan Gambar 3 diketahui bahwa DPI dengan frekuensi 1 hingga 4 tersebar di antara Pulau Bangka dan Pulau Belitung. Hal tersebut diduga karena masukan air tawar yang berasal dari sungai-sungai di kedua pulau tersebut membawa banyak nutrien yang berkumpul di laut. Masukan air tawar 


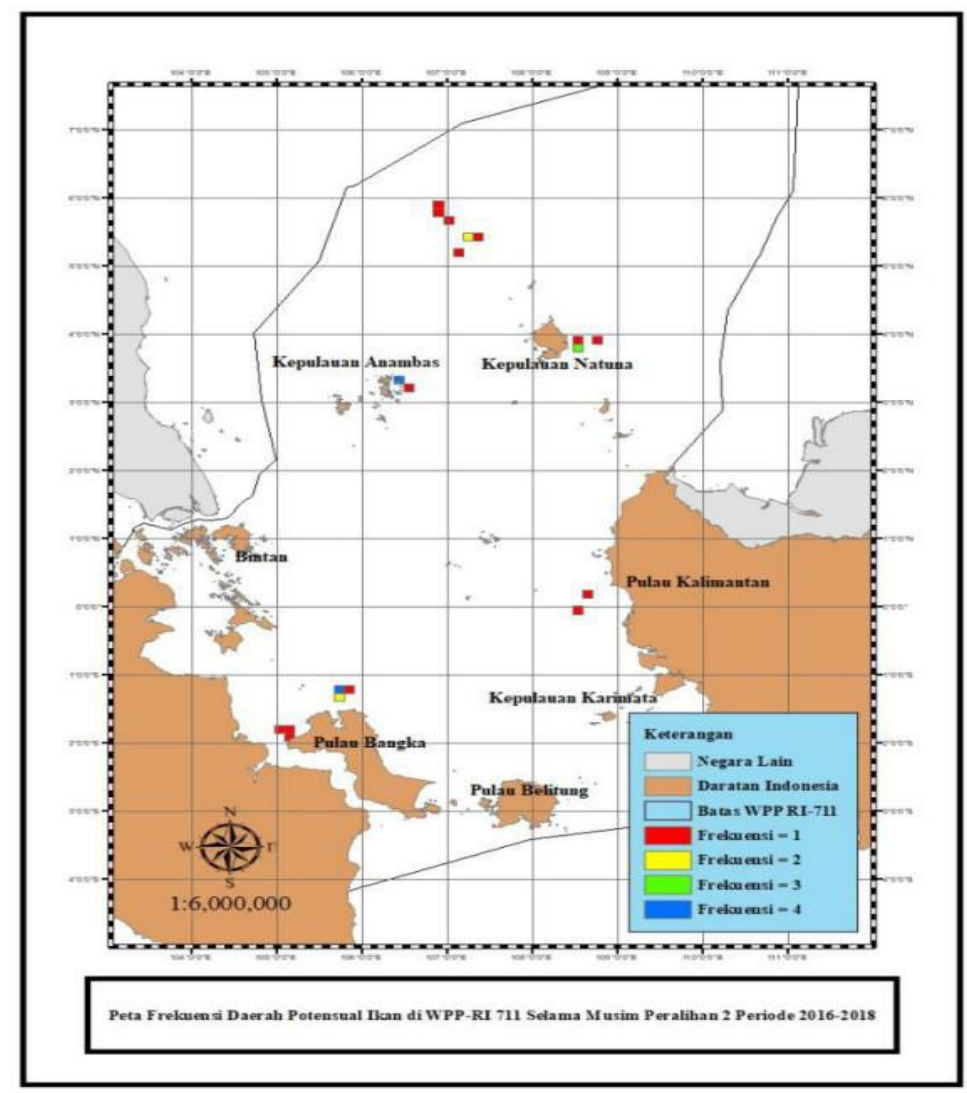

Gambar 4. Peta Frekuensi Daerah Potensial Ikan di WPP-RI 711 Selama Musim Peralihan Peralihan 2 (September, Oktober, dan November)

yang memiliki suhu berbeda juga diduga menyebabkan kemunculan thermal fronts sehingga banyak dijumpai DPI di wilayah tersebut. Kondisi angin yang cukup tenang pada musim ini juga diduga salah satu faktor yang menyebabkan masukan air tawar tidak tersebar terlalu jauh dari kedua pulau tersebut. Pada musim ini DPI terbanyak ditemukan di antara Pulau Bangka dan Pulau Belitung.

\subsection{Sebaran Daerah Potensial Ikan Selama Musim Peralihan 2}

Pada Musim Peralihan 2 keberadaan DPI tidak cukup banyak seperti pada musim barat dan musim peralihan 1 , namun lebih banyak daripada ketika musim timur. Terdapat 19 buah DPI pada musim ini, 14 buah dengan frekuensi 1, 2 buah dengan frekuensi 2, 1 buah dengan frekuensi 3 dan 2 buah dengan frekunsi 4 seperti pada Gambar 4.

Pada musim ini, 4 buah DPI dengan frekuensi 1 dijumpai di sebelah utara Pulau Bangka, 2 buah di bagian barat Pulau Kalimantan, 1 buah di Kepulauan Anambas, 2 buah di sebelah timur Kepulauan Natuna, dan 5 buah di barat laut Kepulauan Natuna serta berbatasan dengan batas WPP-RI 711.
Terdapat 2 buah DPI dengan frekuensi 2, 1 buah terletak di selatan Pulau Bangka dan 1 buah lagi di barat laut Kepulauan Natuna. Selain itu juga terdapat 1 buah DPI dengan frekuensi 3 yang terletak di sebelah timur Kepualauan Natuna. DPI dengan frekuensi 4 ditemukan 1 buah di selatan Pulau Bangka dan 1 buah lagi di sekitar Kepulauan Anambas.

Pada Musim Peralihan 2, kondisi angin masih cukup tenang namun sudah lebih cepat daripada ketika Musim Timur. Selain itu bumi bagian utara sedang mengalami musim gugur, sehingga suhu udara di bumi bagian utara mulai menurun. Pergerakan arah angin yang menuju utara diduga menjadi salah satu penyebab keberadaan DPI di bagian Utara Kepulauan Natuna.

\section{Ucapan Terima Kasih}

Keberadaan DPI terbanyak terjadi pada musim peralihan 1 dengan jumlah DPI sebanyak 70 buah, sebaliknya DPI paling sedikit pada Musim Timur dengan jumlah DPI sebanyak 14 buah. Peningkatan jumlah DPI terjadi mulai Musim Barat sampai Musim Peralihan 1, sebaliknya penurunan jumlah DPI terjadi pada Musim Timur, dan 
kembali mengalami kenaikan pada Musim Peralihan 2 hingga pada Musim Barat.

\section{Daftar Pustaka}

Balai Riset dan Observasi Laut (BROL). 2018. Pembuatan Peta Prediksi Daerah Penangkapan Ikan : MODUL Seri 1 Pelabuhan. Jembrana : BROL.

Cayula, J. F. and Cornillon, P. 1992. Edge Detection Algorithm for SST Images. Journal of Atmospheric and Oceanic Technology. $9(1): 67-80$.

Jatisworo, D., dan Murdimanto, A. 2013. Identifikasi thermal front di Selat Makassar dan Laut Banda. Prosiding Simposium Nasional Sains Geoinformasi III. Yogyakarta, Indonesia.

Kurniawan, A.; Permanasari, Y. dan Sukarsih, I. 2015. Pemanfaatan Suhu Permukaan Laut Citra Penginderaan Jauh Modis Terra/Aqua Untuk Identifikasi Wilayah Berpotensi Ikan. Prosiding Penelitian SPeSIA 2015.

LAPAN. 2014. Pengembangan Model Pemanfaatan Data Satelit NPP dan Altimetri Untuk Penentuan Zona Potensi Penangkapan Ikan. Jakarta : LAPAN.

Roberts, J. J.; Best, B. D.; Dunn, D. C.; Treml, E. A. and Halpin, P. N. 2010. Marine Geospatial Ecology Tools: An integrated framework for ecological geoprocessing with ArcGIS, Python, $\mathrm{R}$, MATLAB, and $\mathrm{C}++$. Elsevier, Environmental Modelling \& Software. Vol. $25: 1197$ - 1207.

Safitri, I. dan Adelita, K. 2018. Perikanan Tangkap Gillnet di Pelabuhan Perikanan Nusantara (PPN) Pemangkat Kalimantan Barat. Jurnal Laut Khatulistiwa. 1(1): 19-24.

Simbolon, D. dan Tadjuddah, M. 2008. Pendugaan Front dan Upwelling Melalui Interpretasi Citra Suhu Permukaan Laut dan Klorofil-a di Perairan Wakatobi Sulawesi Tenggara. Buletin PSP, Vol. XVII No. 3.

Suniada, K. I.; Susilo, E. dan Hastuti, A. W. 2015. Validasi Peta Prakiraan Daerah Penangkapan Ikan (PPDPI) di Perairan Laut Jawa (WPP-R1 712). Prosiding Forum Nasional Sains dan Teknologi Kelautan dan Perikanan 2015.

Suniada, K. I.; Susilo, E. dan Hastuti, A. W., 2016. Variasi Bulanan Daerah Prediksi Penangkapa Ikan di Wilayah Pengelolaan Perikanan RI 711. Prosiding Seminar Nasional Pengelolaan Pesisir dan Daerah Aliran Sunga Ke-2 2016.

Susanto, R. D.; Gordon, A. L. and Zeng, Q. 2001. Upwelling Along the Coasts of Java and Sumatera and its Relation to ENSO. Geophysical Research Letters. 28 (8): 1599-1602. 